\title{
STRATEGI PELAYANAN PASTORAL KONSELING SEBAGAI UPAYA MENINGKATKAN ANTUSIASME JEMAAT DALAM BERIBADAH
}

\author{
Florentina Sianipar
}

\section{PENDAHULUAN}

Kehidupan orang percaya tidak dapat dilepaskan dari kebutuhan untukberibadah, sebab manusia diciptakan Tuhan sebagai makhluk rohaniah. Didalam suatu ibadah akan terjadi persekutuan yang intim antara manusia sebagai yang dicipta dan Allah sebagai pencipta, sehingga manusia dapat merasakan dan memberi respons dengan kerendahan hati menyatakan penghormatan, dan kekaguman terhadap penciptanya.Ketika orang percaya mengerti tentang pengertian ibadah yang benar, maka jemaat akan mengalami perubahan dalam menunjukkan antusiasme ibadahnya. Pengertian antusiasme beribadah disini adalah kegairahan, gelora semangat dan minat yang besar terhadap sesuatu ${ }^{1}$, yaitu untuk datang beribadah ke gereja sesuai jadwal yang telah dirancang oleh gereja. Antusiasme untuk beribadah akan membuat orang percaya menjadi bergairah dan penuh semangat untuk mencari hadiratNya dan menunjukkan rasa syukur yang mendalam kepada Tuhan.

Pada faktanya sering terjadi dalam diri orang percaya, persoalan antusiasme dalam beribadah berada dalam kondisi yang tidak stabil. Pada saatsaat tertentu yang berhubungan dengan hari besar, maka didapati ada gejala antusiasme yang melonjak. Misalnya saat hari Natal dan Paskah. Antusiasme jemaat dalam beribadah juga mengalami perbedaan dalam peristiwa-peristiwa khusus, misalnya: cenderung terjadi lonjakan kehadiran manakala dihadirkan pengkhotbah yang terkenal (artis) dalam ibadah. Bahkan penulis juga menjumpai bahwa ada beberapa jemaat yang jauh lebih bersemangat untuk datang dalam KKR-KKR yang membawa tema mujizat kesembuhan tetapi dalam ibadah jadwal rutin hari minggu tidak pernah menunjukkan antusiasme yang sama. Apabila merujuk pada definisi tentang ibadah, tentunya bukan ibadah yang demikian yang disebut sebagai beribadah yang benar.

Akan menjadi suatu permasalahan yang mampu membahayakan iman kekristenan manakala orang percaya menunjukkan indikator-indikator lemahnya antusiasme untuk beribadah, seperti kurang memiliki rasa kebutuhan untuk dekat dengan Tuhannya, tidak memiliki rasa syukur kepada karya Allah,

\footnotetext{
1 Surayin, Kamus Umum Bahasa Indonesia, (Bandung:Yrama Widya, 2010)
} 
tidak memiliki hati yang haus dan lapar akan Firman Tuhan, tidak merindukan jamahan Roh Kudus melalui kuasa penyembahan dan tidak memiliki hasrat untuk datang menyembah dan berbakti kepada Tuhan. Jika hal tersebut berlangsung terus menerus maka apa yang disebutkan sebagai kemerosotan iman akan segera terjadi dalam diri orang percaya. Adanya kemerosotan dalam pendirian iman orang Kristen tak lepas dari lemahnya komitmen yang dimiliki dalam mempertahankan kepercayaannya. Komitmen yang fluktuatif tersebut membuat orang Kristen menjadi tidak konsisten dalam menjaga kualitas pertobatannya.

Kemerosotan iman yang berakar dari ketidakantusiasan jemaat dalam beribadah bukanlah perkara sepele dalam Kekristenan. Hal ini dipandang sebagai persoalan yang mendasar dan mempengaruhi kualitas kerohanian orang percaya. Sebab masalah pertumbuhan iman merupakan masalah dasar dari pekerjaan rohani dan menjadi fokus target pelayanan setiap hamba Tuhan yang melayani jiwa-jiwa. Diperlukan penanganan secara serius dan mendesak dari setiap hamba Tuhan untuk dapat mencegah terjadinya kemunduran dan penurunan kualitas iman yang lebih parah dalam diri jemaat. Jika jemaat kehilangan antusiasme dalam beribadah maka bisa dipastikan kualitas iman orang percaya akan semakin memburuk.

\section{PEMBAHASAN}

\section{Antusiasme}

Menurut Kamus Umum Bahasa Indonesia, antusiasme memiliki definisi suatu kegairahan, gelora semangat dan minat yang besar terhadap sesuatu. ${ }^{2}$ Dari pengertian tersebut maka dapat disimpulkan bahwa antusiasme berhubungan erat dengan motif sebab rasa antusias lahir dari sebuah motivasi. Tanpa motivasi maka tidak ada sikap antusiasme. Ada prinsip-prinsip dasar yang sama antara motivasi, motif dan antusiasme, yaitu sama-sama mengandung unsur kegairahan, minat yang besar terhadap sesuatu, adanya daya gerak, semangat dan aktif sehingga melahirkan daya upaya untuk mencapai kepuasan. Hal-hal ini dapat terjadi dan dirasakan baik oleh individu tersebut maupun oleh orang lain yang ada disekitarnya. Dalam pembahasan selanjutnya pengertian tentang antusiasme yang penulis gunakan adalah: sikap hati bersungguh-sungguh yang ditunjukkan melalui minat, semangat, dan gairah secara aktif untuk melakukan sesuatu.

\section{Jemaat}

Untuk membahas mengenai pengertian jemaat, tentunya tidak dapat dipisahkan dari definisi orang percaya. Fee menjelaskan bahwa yang disebut

2 Surayin, Kamus Umum Bahasa Indonesia, (Bandung: Yrama Widya, 2010) 
sebagai orang percaya adalah bagian dari tubuh Kristus, yaitu mereka semua yang dibabtis dalam realitas yang sama, yaitu Roh Kudus; dan mereka semuanya diberi minum (diberi ajaran) dari realitas yang sama yaitu Roh Kudus, sehingga membentuk satu tubuh dalam Kristus. ${ }^{3}$ Dari definisi ini kita tahu bahwa orang percaya adalah wujud dari karya keselamatan Tuhan Yesus yang telah diterima sebagai Juru Selamat secara pribadi sehingga ia menjadi bagian dari tubuh Kristus sendiri.

Sehubungan dengan orang percaya sebagai bagian dari gereja Tuhan, Wongso menulis: unsur dasar gereja ialah orang-orang percaya yang sudah mendapat hidup kekal, hanya Roh Kudus yang dapat memberikan hidup kekal kepada orang yang percaya dan menerima Tuhan Yesus sebagai Juru Selamat (Yoh 1:12; 3:5,8). ${ }^{4}$ Jadi gereja Tuhan yang terdiri dari orang-orang percaya harus diisi oleh orang-orang yang merindukan Roh Kudus untuk berkarya dalam hidupnya dan telah menerima Tuhan Yesus Kristus sebagai Juru Selamat secara mutlak untuk mengerjakan keselamatan secara penuh dalam hidupnya.

Penyebutan kata umat Allah bisa juga diartikan sebagai jemaah atau jemaat. Oleh karena itu penulis mendefinisikan istilah 'jemaat' sebagai sekumpulan orang percaya yang telah menerima karya keselamatan Tuhan Yesus Kristus dan meyakini karya Roh Kudus serta memiliki kesediaan untuk mengerjakan keselamatan itu dalam hidupnya.

\section{Ibadah}

Kata ibadah dalam Bahasa Inggris "worship" berasal dari bahasa Anglo-Saxon "weorthscipe" dari kata "worth" dan "ship" berarti seseorang yang "worthy of reverence an honor". 5 Maka ketika beribadah ada pengakuan bahwa hanya Dia, dalam hal ini Allah yang layak untuk disembah. Selain itu John Piper yang dikutip oleh Berkley menuliskan bahwa "worship is the adoration and praise of that which delight us". ${ }^{6}$ Pernyataan ini jelas menunjukkan adanya bentuk pengakuan manusia atas keutamaan dan kemuliaan Allah dalam aktifitas ibadah.

Kata ibadah sebenarnya berasal dari kosa kata "äbodah" (bahasa Ibrani) atau ibadah (bahasa Arab) yang secara harafiah berarti bakti, hormat,

\footnotetext{
3 Gordon D. Fee, Paulus, Roh Kudus dan Umat Allah, (Malang:Gandum Mas, 2004), 97

4 Peter Wongso, Tugas Gereja dan Misi Masa Kini, (Malang: Depart Literatur SAAT, 1999), 102 1996), 5

5 Franklin M. Segler, Christian Worship, (Tennessee : Broadman \& Holman Publiser,

6 James D. Berkley, Leadership Handbook of Preaching and Worship, (Manila : Christian Letarature Crusade, 1992),171
} 
penghormatan, ${ }^{7}$ suatu "sikap dan aktivitas" yang mengakui dan menghargai seseorang (atau yang ilahi). Atau dapat juga dikatakan suatu penghormatan hidup yang mencakup kesalehan (yang diatur dalam suatu tatacara), yang implikasinya nampak dalam tingkah laku dan aktivitas kehidupan sehari-hari. Jadi ibadah disini merupakan ekspresi dan sikap hidup yang penuh bhakti (penyerahan diri) kepada yang ilahi, yang pengaruhnya nampak dalam tingkah laku yang benar.Dalam kesaksian Alkitab ada beberapa kata atau ungkapan yang dipakai untuk ibadah. Kata kerja äbad (Bahasa Ibrani) berarti melayani atau mengabdi (seperti pengabdian/pelayanan yang utuh dari seorang hamba kepada tuannya). ${ }^{8}$ Sedangkan kata àbodah (bahasa Ibrani), latria (bahasa Yunani) berarti pelayan atau bisa juga berarti pemujaan dan pemuliaan. ${ }^{9}$ Disamping itu kita juga bertemu dengan kata histaaweh (proskuneo; bahasa Yunani) yang berarti sujud atau membungkuk atau meniarap di hadapan tuannya. ${ }^{10}$ Jadi sebenarnya ada dua kata kunci dalam pengertian ibadah itu, yaitu sikap hormat (pemuliaan) dan pelayanan (sikap hidup). Dari pengertian di atas, menjadi jelas bahwa konsep dasar dari ibadah adalah pelayanan atau pengabdian seutuhnya dari hidup kita kepada Allah, yang dinyatakan baik dalam bentuk penyembahan (kultus) maupun dalam tingkah laku kita terhadap orang-orang yang ada disekitar kita.

Pada awalnya kita menemukan adanya ibadah atau persembahan pribadi kepada Allah (Kej. 4:4 Habel memberikan persembahan kepada Tuhan; lihat pula, Kel. 24:26). Hal itu menunjukkan bahwa pada dasarnya ibadah adalah merupakan ungkapan bathin seseorang yang mengakui bahwa Allah berdaulat, penuh kuasa dan baik. Ibadah hendak menunjukkan ketinggian spritual seseorang yang disertai ungkapan pujian dan syukur kepada Tuhan, karena Ia adalah Allah yang patut disembah (bd. Ayub 1:20 ; Yos. 5:14). Harus dipahami bahwa Allah kita adalah Allah yang transenden dan imanen. Allah yang "tidak sama dan terpisah dari ciptaanNya" tapi juga sekaligus Allah yang berkomunikasi dengan umat manusia.

Ibadah juga berkaitan dengan kewajiban-kewajiban agama, yakni melaksanakan perintah-perintah Tuhan (Ul.11:8-11). Bahkan dalam Perjanjian Lama, konsep ibadah pada hakekatnya bukan hanya pelaksanaan upacara keagamaan di tempat-tempat ibadah, akan tetapi adalah mencakup pelaksanaan kewajiban agama, seperti : sunat, puasa, pemeliharaan Sabat, torat dan doa sebab ibadah juga harus mengandung makna bagi hidup susila. Senada dengan ini, Basden menulis: dalam kisah keluarnya bangsa Israel dari Mesir, ibadah menjadi dasar dan sebagai dasar pola untuk semua bentuk ibadah masa depan.

7 A. Cronbach, Worship in Old Testament, dalam The Interpreter's Dictionary of the Bible. Editor by G.A. Buttrick, R-2, (Nashville, Abingdon Press, 1982), 879.

8 New Bible Dictionary, (Leicester: Inter-Varsity Press, 1967), 1262

9 A. Cronbach, Worship in Old Testament, dalam The Interpreter's Dictionary of the Bible. Editor by G.A. Buttrick, R-2, (Nashville, Abingdon Press, 1982), 879

10 New Bible Dictionary, (Leicester: Inter-Varsity Press, 1967), 1262 
Allah menyelamatkan umat-Nya dari perbudakan adalah peristiwa penting dalam Perjanjian Lama. Inilah salib dan kebangkitan dalam Perjanjian Lama yang digenapi di dalam Perjanjian Baru. ${ }^{11}$

Sehubungan dengan tata cara ibadah jemaat kepada Allah Basden menjelaskan: dalam kemah pertemuan dan dalam Bait Suci tata upacara ibadah adalah yang utama. Alkitab menunjukkan kepada kita bahwa ibadah secara mendasar adalah merupakan satu respons sebagai pribadi atau sebagai jemaat kepada perbuatan Allah yang Mahatinggi. Tentunya jemaat dalam merespon kebaikan Allah akan dengan kerelaan hati menaikkan ucapan syukur dan pujian hanya bagi namaNya di dalam Ibadah.

Mengenai bagaimana ekspresi utama yang lahir dari diri jemaat di dalam melakukan ibadah ini Basden juga memaparkan: termasuk mempersembahkan korban binatang pada Paskah (Kel.12:1-28), mempersembahkan semua yang sulung atau pertama lahir kepada Tuhan menjadi milik Tuhan (Kel.13:1-2), dan menyanyikan puji-pujian dengan sorak sorai dan penuh kemenangan yang dipimpin oleh Musa dan Miriam (Kel.15: 121). Dari penjelasan ini penulis menggarisbawahi bahwa unsur aktifitas yang dilakukan jemaat Tuhan saat beribadah, sebagai bagian dari ekspresi ucapan syukur diantaranya adalah dengan mempersembahkan sesuatu kepada Tuhan dan menyanyikan puji-pujian bagi Tuhan.

Apabila sekumpulan umat Allah memiliki hati yang suka beribadah, senantiasa merindukan ibadah, bersemangat dalam melakukan ibadahnya dan benar-benar menikmati hubungan yang intim dengan Tuhan maka secara berkesinambungan sekumpulan umat Allah ini akan memiliki suatu hubungan yang sungguh-sungguh erat dan berkualitas dengan Tuhan. Rohaninya akan mengalami pertumbuhan dan pendewasaan. Menghubungkan antara kualitas iman orang percaya dalam gereja Tuhan dengan pertumbuhan gereja, menurut Wongso pertumbuhan gereja ialah pertumbuhan kualitas dan kuantitas hidup orang Kristen (Kis. 2: 37-41, 4:4).

Luasnya lingkup dan pengertian ibadah membuat penulis merasa perlu untuk melakukan pembatasan konsep tentang ibadah dalam penelitian ini. Oleh karena itu dalam pembahasan selanjutnya penulis menggunakan arti atas kata 'beribadah' sebagai: memberikan diri secara tulus untuk datang berbakti dan menyembah Tuhan sebagai respon syukur atas kebaikan dan karya penebusanNya melalui kehadiran secara aktif untuk mengikuti kebaktian dan persekutuan dengan jemaat Tuhan. 1999), 20

11 Paul Basden, The Worship Maze, Downers Grove,(Illionis: Inter Varsity Press, 


\section{Pelayanan Pastoral Konseling}

Dalam bukunya yang berjudul "Pastoral Konseling" Susabda mendefinisikan pastoral konseling sebagai hubungan timbal balik (interpersonal relationship) antara hamba Tuhan (pendeta, penginjil, dsb) sebagai konselor dengan konselinya (klien, orang yang minta bimbingan), dalam mana konselor mencoba membimbing konselinya ke dalam suatu suasana percakapan konseling yang ideal (Conducive atmosthpere) yang memungkinkan konseli itu betul-betul dapat mengenal dan mengerti apa yang sedang terjadi pada dirinya sendiri, persoalannya, kondisi hidupnya, di mana ia berada, dsb; sehingga ia mampu melihat tujuan hidupnya dalam relasi dan tanggung jawabnya pada Tuhan dan mencoba mencapai tujuan itu dengan takaran, kekuatan dan kemampuan seperti yang sudah diberikan Tuhan kepadanya. ${ }^{12}$ Definisi tersebut jelas menunjukkan tentang pengertian sekaligus tujuan dari pelayanan pastoral konseling yaitu untuk menyadarkan konseli akan keselarasan hubungan tujuan hidupnya dengan kehendak Tuhan.

Pengertian konseling sendiri banyak dikutip dan ditulis dalam beberapa pengertian yang saling melengkapi. Gintings, dalam bukunya Konseling Pastoral, menjelaskan secara etimologis istilah Counseling, yaitu: Counseling dalam kamus Webster's New Collegiate Dictionary disebutkan berasal dari istilah Latin yaitu consilium yang berati perundingan, pertimbangan, atau musyawarah. Dalam istilah counsilium terdapat unsur dengan atau bersama orang lain; ditambah unsur memahami atau mengambil sari dari pembicaraan, pemikiran, atau ide orang lain. Seterusnya dalam kamus tersebut diperoleh keterangan bahwa secara etimologis, kata counsel berasal dari dua kata yaitu coun dan sel. Kata sel berasal dari Anglo Saxon yaitu sellan yang berarti menjual, tetapi juga berarti membebaskan, menyelamatkan.13 Melalui definisi ini kita dapat mengetahui bahwa dalam proses konseling terdapat proses upaya untuk memahami dan menggali sari pembicaraan, pikiran utama dan menemukenali pokok permasalahan yang tengah dibahas dengan tujuan untuk menyelamatkan atau membebaskan.

Selanjutnya dari penjelasan kata Counseling diatas Gintings menyimpulkan tentang pengertian konseling, yaitu: Counseling adalah suatu perembugan, perundingan yang diadakan bersama atau dengan orang lain untuk mencari suatu jalan keluar atau putusan yang menyelamatkan atau membebaskan sehingga konseling tidak berarti suatu nasehat yang bersifat menolong terhadap orang lain. Dalam perkembangan selanjutnya, konseling menjadi sebuah istilah mengenai kegiatan berbagai macam prosedur kegiatan yang mencakup upaya-upaya seperti memberi nasehat, dorongan, informasi,

12 Yakub B Susabda, Pastoral Konseling Jilid. 1, (Malang: Gandum Mas, 2003), 4

13 E. P. Gintings, Konseling Pastoral, (Bandung: Jurnal Info Media, 2009), 10 
dan menganalisa sesuatu masalah atau fakta.14 Tentunya pelayanan pemberian nasehat, dorongan, informasi demi jalan keluar dari pemecahan masalah yang dihadapi oleh konseli merupakan tujuan mulia dan sangat dibutuhkan oleh manusia dalam segala keberadaannya. Oleh karena itu kegiatan pelayanan pastoral konseling ini sangat perlu dilakukan dalam upaya pengoptimalan pelayanan penggembalaan bagi jiwa-jiwa.

Pelayanan pastoral konseling merupakan pelayanan bagi jiwa-jiwa milik Tuhan, dan hal ini sangat berharga dimata Allah. Dalam pandangan Tuhan Yesus jiwa itu sangat berharga. Sehubungan dengan hal tersebut Wongso menulis: nilai jiwa jauh melebihi segala sesuatu yang ada di dalam dunia. Jika kita mempunyai penilaian yang tinggi terhadap jiwa manusia, maka pasti di dalam pekerjaan penyelamatan jiwa yang penting ini, kita tak akan terjerumus dalam pandangan yang salah,15 bahkan kita akan siap melakukannya. Dengan kata lain, pekerjaan penyelamatan jiwa merupakan sasaran akhir dari pelayanan pastoral konseling ini, sebab ini merupakan bagian dari mandat Tuhan Yesus.

Konseling pastoral harus berakar pada kesadaran triolog sebagai Allah yang berpribadi, sehingga dalam proses konseling pastoral ada konselor dan konseli serta ditengah-tengah mereka hadir Allah di dalam Roh Kudus yang mempengaruhi konselor maupun konseli. ${ }^{16}$ Pendapat ini senada dengan Tomatala yang menyatakan bahwa dalam proses konseling Kristen, Roh Kudus berperan sebagai penuntun dan Firman Allah memberi terang dan hikmat terhadap persoalan yang dihadapi serta dalam memperoleh jalan penyelesaiannya. ${ }^{17}$ Selanjutnya juga dikatakan bahwa Roh Kudus adalah dinamika konseling Kristen. Dalam konseling Kristen, Roh Kudus menuntun konselor Kristen untuk melayani dan sekaligus memulihkan, mengubah serta mendewasakan konseli. ${ }^{18}$ Dengan pernyataan ini kita mengetahui bahwa dalam kegiatan pelayanan pastoral konseling harus melibatkan keberadaan Allah Bapa, Allah Putra dan Allah Roh Kudus dalam penerapannya. Seorang konselor tidak dapat bermegah diri seolah keberhasilan dan ketepatannya dalam melakukan pelayanan konseling berasal dari kemampuannya sendiri, melainkan mutlak menyerahkan segenap prosesnya kepada pimpinan Roh Kudus.

Berbicara mengenai pelayanan Pastoral Konseling tidak dapat dilepaskan dari tujuan pelayanan itu sendiri. Konseling atau penyuluhan adalah proses pemberian bantuan yang dilakukan oleh seorang ahli (disebut konselor / pembimbing) kepada individu yang mengalami sesuatu masalah (disebut

14 E. P. Gintings, Konseling Pastoral, (Bandung: Jurnal Info Media, 2009), 10

15 Peter Wongso, Tugas Gereja dan Misi Masa Kini, (Malang: SAAT,1999),127

16 E.P. Gintings, Konseling Pastoral, (Bandung: Jurnal Info Media, 2009),19

17 Magdalena Tomatala, Konselor Kompeten, Pengantar Konseling Terapi Untuk Pemulihan, (Jakarta: YT Leadership Foundation, 2003), 5

18 Magdalena Tomatala, Konselor..., 15-16 
konseli) yang bermuara pada teratasinya masalah yang dihadapi klien. ${ }^{19}$ Sementara itu Krumboltz mengklarifikasikan tujuan konseling menjadi tiga macam, yaitu : mengubah perilaku yang salah penyesuaian, belajar membuat keputusan, dan mencegah timbulnya masalah. ${ }^{20}$ Dari tiga tujuan konseling tersebut dapat diketahui bahwa perilaku yang salah, yang terjadi dalam diri jemaat, dapat ditolong untuk dipimpin dalam proses penyadaran diri. Setelah terjadi proses penyadaran diri atas perilakunya maka jemaat dapat diarahkan untuk membuat keputusan secara benar dan alkitabiah supaya dalam perjalanan selanjutnya dapat terhindar dari masalah yang mendalam.

\section{Gejala Melemahnya Antusiasme Jemaat Untuk Beribadah}

Namun pada kenyataannya masih terlalu banyak umat Allah yang mengabaikan persoalan ibadah ini. Ada begitu banyak problem kehidupan dihadapi yang membuat jemaat mengurungkan niat mereka untuk datang kepada Tuhan, hal ini memengaruhi intensitas dan antusiasme persekutan jemaat dengan Tuhan. Tentunya hal ini membawa keresahan tersendiri bagi para Hamba Tuhan yang dengan penuh gairah mengobarkan semangat untuk setia beribadah kepada umat Allah.Berkaitan dengan sangat berharganya sebuah ibadah ini, Piper didalam paragraf pembukaan bukunya menulis: "sasaran akhir gereja bukan misi, melainkan ibadah (penyembahan). Misi ada karena ibadah tidak ada. Ibadah adalah sasaran akhir, bukan misi, karena Allah adalah yang utama, bukan manusia. Ketika zaman ini berlalu dan jutaan orang yang tidak terbilang jumlahnya sujud menyembah di depan takhta Allah, maka tidak akan ada lagi misi. Misi adalah kebutuhan yang sementara. Tetapi ibadah akan ada untuk selama-lamanya". ${ }^{21}$ Pentingnya kegiatan ibadah ini membuat gereja seharusnya terbeban dengan belum maksimalnya kesetiaan jemaat dalam mengerjakan keselamatannya melalui antusiasme dalam beribadah. Padahal ibadah merupakan sasaran akhir yang menjadi ujung atas pengabdian manusia kepada Allah. Kalau kegiatan ibadah hanya dikerjakan dengan seadanya dan biasa-biasa saja tanpa rasa antusiasme yang tinggi maka bisa dipastikan kualitas ibadah itu sendiri akan mengalami degradasi waktu demi waktu. Kelemahan antusiasme jemaat dalam beribadah yaitu: jemaat pada umumnya menunjukkan sikap yang tidak antusias, tidak sungguh-sungguh dan tidak bergairah dalam mengikuti ibadah di gereja. Hal-hal yang menjadi penyebab lemahnya antusiasme jemaat dalam beribadah yaitu: Jemaat masih memiliki persoalan pelik dalam kehidupan pribadinya yang belum terselesaikan sehingga membuatnya menjadi tidak antusias dalam mengikuti

19 Id.m.wikipedia.org/wiki/konseling

20 Latipun, Psikologi Konseling, (Malang:Unmuh, 2001), 37-40

${ }^{21}$ John Piper, Let the Nation be Glad! The Supremacy of God in Missions, (Baker Book House, Grand Rapids: 1993),1 
ibadah serta jemaat rata-rata tidak memiliki hubungan pribadi dengan Tuhan secara indah.

Melemahnya sikap antusiasme merupakan hal yang membahayakan kerohanian, apabila terjadi secara terus menerus akan membuat jiwa kehilangan semangat, gairah, kesungguhan dan totalitas untuk mencari dan menikmati hadirat Tuhan. Allah yang Maha Baik rindu umatnya selalu meresponi kebaikan dan anugerah keselamatanNya melalui datang beribadah, menaikkan ucapan syukur dan menyembahNya. Sebab pemilihan keselamatan dari Tuhan Yesus Kristus merupakan karya terbesar dalam sejarah hidup orang percaya.

Apabila persoalan antusiasme tidak segera diatasi, gereja akan mengalami kesulitan dalam mewujudkan tujuan gereja untuk pertumbuhan dan pendewasaan rohani jemaat. Kerohanian jemaat akan mengalami kegersangan dan jauh dari kematangan. Menciptakan kondisi jemaat dengan iman yang kerdil, kekanak-kanakan, mudah patah arang, terhanyut dalam rupa-rupa angin pengajaran dan penyesatan bahkan memiliki pemahaman yang salah dalam menjalankan prinsip-prinsip kekristenan dalam hidupnya.

Untuk itu gereja harus segera melangkah untuk memperbaiki dan meningkatkan kembali antusiasme jemaat dalam beribadah dengan cara: pertama, jemaat yang memiliki persoalan dalam kehidupan pribadi dan belum terselesaikan sehingga menghalangi ibadahnya harus segera dilakukan pemulihan melalui pelayanan pastoral konseling. Jiwa yang tengah bergumul ini harus cepat ditangani. Artinya setiap hamba Tuhan yang merasa terbeban dengan jiwa-jiwa yang demikian, seharusnya segera memprioritaskan untuk datang menjemput bola guna melakukan pelayanan pastoral. Dengan melakukan pelayanan pastoral konseling, konselor dapat memberikan empati, dapat mengidentifikasi titik masalah, mengarahkan kepada pengambilan keputusan yang benar dan Alkitabiah, serta mengajak jemaat mengalami pemulihan hubungan kembali dengan Tuhan. Pendapat ini dikuatkan Susabda: sebagai orang Kristen konsele harus diajar untuk melihat tujuan hidup lebih daripada "kebahagiaan"nya sendiri. Tentunya melalui konseling, jemaat diajak untuk mengarahkan hidupnya untuk meraih perkenanan Tuhan melalui respon yang benar untuk beribadah.

Kedua, jemaat terus menerus dimotivasi untuk memiliki hubungan yang indah dengan Tuhan melalui komitmen pribadinya. Sebab manusia sebagai peta dan gambar Allah adalah makhluk yang mempunyai Roh. Makhluk rohani yang punya kemampuan berkomunikasi dan bersekutu dengan Khaliknya. $^{22}$ Jemaat diajak untuk selalu memiliki komunikasi yang indah dengan Tuhan.

${ }^{22}$ Yakub B. Susabda, Pastoral Konseling Jilid 2, (Malang: Gandum Mas, 2000), 205 


\section{Strategi}

Menurut kamus Webster's: Strategi adalah keahlian dalam melakukan suatu pekerjaan dan pengkoordinasian berbagai taktik. ${ }^{23}$ Sementara itu menurut Wikipedia, strategi adalah pendekatan secara keseluruhan yang berkaitan dengan pelaksanaan gagasan, perencanaan dan eksekusi sebuah aktifitas dalam kurun waktu tertentu. ${ }^{24}$ Dari kedua pengertian tersebut dapat dirumuskan bahwa kata 'strategi' memiliki definisi: penerapan suatu keahlian dalam mengoordinir berbagai upaya dengan menggunakan berbagai pendekatan untuk melaksanakan sebuah gagasan dalam kurun waktu tertentu.

Siagian dalam bukunya yang berjudul Manajemen Strategik menyatakan bahwa strategi adalah serangkaian keputusan dan tindakan mendasar yang dibuat oleh manajemen puncak dan diimplementasikan oleh seluruh jajaran suatu organisasi dalam rangka pencapaian tujuan organisasi tersebut. ${ }^{25}$ Bertolak dari pernyataan tersebut dapat diketahui bahwa strategi, baik dalam perencanaan, pelaksanaan maupun evaluasinya, memerlukan pertimbangan dan dasar tindakan yang kuat dan fundamental dari seseorang yang dianggap sebagai pemimpin, selanjutnya seluruh jajaran dalam organisasi tersebut melaksanakan keputusan dengan terarah dalam rangka pencapaian tujuan.

Tentunya strategi yang diharapkan untuk diperjuangkan dan diterapkan adalah strategi yang baik dan efektif. Terkait penerapan strategi yang baik Siagian menulis: Di dalam strategi yang baik terdapat koordinasi tim kerja, memiliki tema, mengidentifikasi faktor pendukung yang sesuai dengan prinsipprinsip pelaksanaan gagasan secara rasional, efisien dalam pendanaan dan memiliki taktik untuk mencapai tujuan secara efektif. Strategi dibedakan dengan taktik yang memiliki ruang lingkup yang lebih sempit dan waktu yang lebih singkat. ${ }^{26}$ Dari pengertian tersebut penulis menyimpulkan bahwa untuk menerapkan sebuah strategi secara baik diperlukan unsur-unsur pengkoordinasian tim kerja secara baik, adanya rencana atau target yang akan diraih, perlunya mengidentifikasi faktor-faktor pendukung, penguatan prinsipprinsip gagasan dan menerapkan cara-cara tertentu demi pencapaian tujuan secara efektif.

\footnotetext{
23 Webster's dictionary (2000: 725)

24 Id.m.wikipedia.org/wiki/strategi

${ }^{25}$ Siagian P. Sondang, Manajemen Stratejik, (Jakarta : Bumi Aksara, 2008, 15)

${ }^{26}$ Siagian P. Sondang, Manajemen Stratejik, (Jakarta : Bumi Aksara, 2008, 15)
} 


\section{Strategi Pelayanan Pastoral Konseling Bagi Peningkatan Antusiasme Jemaat Dalam Beribadah Di Gereja}

Kelemahan peran pelayanan pastoral konseling bagi jemaat adalah: kegiatan pelayanan pastoral konseling bagi jemaat tidak dapat berperan secara benar dan efektif. Yang menjadi penyebab lemahnya peran pelayanan pastoral konseling bagi jemaat adalah: (a) Gereja belum memiliki hamba Tuhan konselor yang mampu melakukan pelayanan pastoral konseling secara benar dan efektif. (b) Gembala sidang tidak berdomisili di antara jemaat, fungsi penggembalaan dialihkan kepada pelayan sekretariat dan pengerja fulltime yang ditugaskan dari pusat. Hal ini menyebabkan kurang maksimalnya fungsi pelayanan penggembalaan bagi jemaat.(c) Hamba Tuhan dan pelayan yang ada tidak pernah diberikan pembekalan atau peningkatan kapasitas untuk menjadi seorang konselor yang efektif.

Penulis berpendapat bahwa gereja seharusnya melengkapi pelayanannya bagi jiwa secara menyeluruh. Gereja jangan hanya terfokus pada tata liturgi dan pelayanan altar, tetapi juga harus memperhatikan kebutuhan dalam diri jemaat. Kebutuhan jemaat bukan hanya untuk mengikuti liturgi ibadah tetapi juga membutuhkan suatu daya dorong untuk menghadapi krisiskrisis dalam kehidupannya. Bahkan jemaat juga membutuhkan kekuatan yang lebih untuk memahami kebenaran Alkitab. Jelaslah bahwa peran pelayanan pastoral konseling sangat menolong jemaat untuk mengatasi berbagai krisis dalam hidupnya.

Cara memperbaiki kondisi tersebut adalah: pertama, gereja harus segera menyediakan hamba Tuhan konselor yang cakap dan terampil dalam melakukan pelayanan pastoral konseling. Baik itu dengan memaksimalkan potensi hamba Tuhan dari sumber daya manusia yang ada di gereja ataupun dengan meminta bantuan dari hamba Tuhan eksternal yang diketahui memiliki talenta dan kecakapan untuk pelayanan konseling. Sebab sebagaimana Susabda menulis: pelayanan pastoral konseling adalah pelayanan hamba Tuhan yang dipercayakan oleh Allah sendiri ${ }^{27}$ maka pelayanan ini tidak dapat dilakukan oleh sembarangan orang atau asal tunjuk saja.

Kedua, gembala perlu menyadari bahwa setiap tanggung jawab yang diembankan kepada seorang gembala, tidak dapat dialihkan kepada orang lain, walaupun kepada sekretariat, pengerja atau kepada sesama rekan hamba Tuhan. Sebagai pemimpin jemaat, maka gembala memiliki tanggung jawab penuh terhadap kerohanian jemaat. Hal-hal yang mempengaruhi naik turunnya kerohanian jemaat, harus menjadi perhatian gembala. Indra menuliskan bahwa Allah memiliki tujuan untuk manusia, yaitu menjadi seperti Kristus. Gembala dan hamba Tuhan bertugas mengubah karakter dan perilaku pendengar, yang

${ }^{27}$ Yakub B. Susabda, Pastoral Konseling Jilid 1, (Malang: Gandum Mas, 2003), 49 
adalah jemaat, membawa mereka kepada kedewasaan, pelayanan, dan misi. ${ }^{28}$ Ini berarti gembala bertanggung jawab untuk memimpin jemaat kepada suatu pertumbuhan rohani menjadi seperti Kristus. Apabila gembala dalam tugas pelayanannya sebagai pemimpin jemaat, dikarenakan jarak domisili tempat tinggalnya jauh dari jemaat maka gembala dapat mendelegasikan tugas tersebut kepada staf/pengerja lain, namun bukan berarti gembala mendelegasikan seluruh tanggung jawabnya kepada staf/para pengerja tersebut. Yang perlu menjadi catatan penting gembala adalah, bahwa yang didelegasikan adalah tugas pelayanan, bukan tanggung jawab pelayanan. Artinya, walaupun tugas tersebut dikerjakan oleh staf/ para pengerja gereja, tetapi gembala harus tetap bertanggung atas tugas pelayanan tersebut, dapat dilakukan dengan beberapa cara diantaranya membuat perencanaan pelayanan, selalu memantau perkembangannya dan melakukan evaluasi hasil tindak lanjut. Dalam hal ini, peneliti berpendapat bahwa penting bagi gembala untuk lebih memperhatikan pelayanan pastoral konseling dengan mengatur waktu untuk melakukan kunjungan pastoral ke rumah jemaat atau untuk melayani konseling sehingga gembala melakukan peran pelayanan pastoral konseling bagi jemaat secara optimal. Ini berarti gembala sebagai pemimpin jemaat diharapkan senantiasa berada di tengah-tengah jemaat. Gembala seharusnya mengetahui bagaimana kondisi jemaat, baik itu kesehariannya, keluarganya, pekerjaannya, hingga kepada krisis-krisis apa yang tengah dihadapi jemaat. Apabila gembala tidak mengetahui kondisi jemaat yang sebenarnya maka gemba akan kesulitan dalam melakukan pelayanan pastoral konseling.

Ketiga, gereja perlu segera melakukan pembekalan dan peningkatan kapasitas bagi para hamba Tuhan setempat yang berpotensi untuk dapat melakukan pelayanan pastoral konseling bagi jemaat. Bentuk pembekalan dapat dilakukan melalui mengirimkan hamba Tuhan untuk mengikuti tugas belajar, mengikutkan hamba Tuhan setempat dalam acara seminar atau dengan mengadakan pendalaman Alkitab tentang pelayanan pastoral konseling di gereja dengan menghadirkan pembicara. Dengan melakukan pembekalan dan peningkatan kapasitas hamba Tuhan di bidang pastoral konseling, maka kualitas pelayanan pastoral konseling bagi jemaat dapat diperbaiki dan ditingkatkan efektifitasnya. Pendapat ini dikuatkan oleh Sudabda: jikalau hamba Tuhan mengerti akan hal ini barulah dalam pelayanan konseling mereka tidak akan melakukan kesalahan-kesalahan yang naif, seperti misalnya memakai Alkitab hanya secara harfiah (dimana ayat-ayat Alkitab menjadi mantera yang menimbulkan efek-efek psikis tersendiri) mereka juga akan dibebaskan dari sikap yang keliru terhadap discovered trusth (sumbangansumbangan psikologi). ${ }^{29}$ Selain itu pengetahuan yang benar akan menolong

\footnotetext{
${ }^{28}$ Ichwei G. Indra, A Blessing Church Studi Eklesiologi Praktis, (Surabaya: Pelayanan Mandiri "Mikhael", 2008), 43

29 Yakub B. Susabda, Pastoral..., 62
} 
hamba Tuhan dalam melayani konseling, salah satunya yaitu untuk membedakan tingkah laku normal dari orang-orang yang memang harus menjadi tanggung jawab mereka dan tingkah laku abnormal dari orang-orang yang seharusnya menjadi tanggungjawab profesional-profesional lain. ${ }^{30}$ Gereja jangan sampai menyepelekan untuk memperlengkapi hamba Tuhan konselor dengan pemahaman tentang konseling secara benar. Melalui pembekalan dan peningkatan kapasitas hamba Tuhan konselor akan dapat mengefektifkan pelayanan pastoral konseling bagi jemaat dan menghindarkan diri dari kesalahan-kesalahan dalam pelayanan konseling.

Kelemahan peran pelayanan pastoral konseling bagi peningkatan antusiasme jemaat dalam beribadah di gereja, yaitu: gereja belum memberikan perhatian dan penanganan secara tanggap, cepat dan serius dalam menindaklanjuti lemahnya antusiasme jemaat dalam beribadah di gereja. Yang menjadi penyebab lemahnya peran pelayanan pastoral konseling bagi peningkatan antusiasme jemaat dalam beribadah di gereja adalah : Gereja kurang bisa memberikan bantuan dalam bentuk pelayanan pastoral konseling bagi jemaat yang mengalami persoalan-persoalan dalam kehidupan pribadi. Alasan berikutnya adalah Gereja kurang bisa memberikan bantuan dalam bentuk pelayanan pastoral konseling bagi jemaat yang mengalami kelemahan dalam antusiasme beribadah di gereja.

Penulis juga berpendapat bahwa gereja perlu lebih memfokuskan diri untuk dapat memberikan bantuan dalam bentuk pelayanan pastoral konseling bagi jemaat yang mengalami persoalan-persoalan dalam kehidupan pribadi. Sebab, sebuah gereja yang sehat ia memiliki kemampuan untuk mengadakan penyembuhan bagi anggota yang terluka.Inilah peran gereja yang memaknai pelayanan Tuhan Yesus yaitu melakukan penyembuhan. Gereja melalui segenap jajaran pelayan di dalamnya perlu secara sungguh-sungguh mengemban tugas pelayanan ini secara serius. Seharusnya gereja perlu lebih memberikan bantuan dalam bentuk pelayanan pastoral konseling bagi jemaat yang mengalami kelemahan dalam antusiasme beribadah di gereja. Penulis menekankan bahwa peran pelayanan pastoral konseling bagi jemaat adalah untuk memberikan pertolongan agar posisi kerohanian jemaat berada pada kondisi yang tepat dan sehat. Ketika jemaat mengalami kelemahan rohani dalam antusiasmenya untuk datang dan beribadah di gereja maka dipastikan jemaat sedang dalam posisi membutuhkan bentuk pertolongan secara psikologis. Gereja perlu menyadari bahwa titik peran pelayanan pastoral konseling sangat diperlukan untuk menyikapi persoalan ini.

Yang menjadi penyebab lemahnya strategi pelayanan pastoral konseling guna meningkatkan antusiasme jemaat dalam beribadah di gereja adalah: (a) Gembala belum memiliki rencana program, target dan sasaran kerja yang jelas untuk melaksanakan peran pelayanan pastoral. (b) Gereja belum

30 Ibid., 75 
memaksimalkan berbagai fasilitas yang ada untuk menunjang pelayanan pastoral konseling secara lebih efektif. (c) Gembala belum mengoordinir tim pelayanan yang ada dengan baik. Masing-masing pelayan berjalan sendiri dan kurang bisa bekerjasama dengan baik.

Penulis berpendapat bahwa gereja perlu merumuskan strategi untuk meningkatkan antusiasme jemaat dalam beribadah di gereja. Strategi yang dapat dirancang yaitu: pertama, Gembala perlu menyusun rencana atau program pelayanan pastoral konseling. Gembala perlu menyampaikan targettarget dalam pelayanan yang harus dilakukan oleh tim pelayanan dan staff. Target pelayanan dalam hal ini jelas adalah bagi jiwa-jiwa. Fokus gereja seharusnya memikirkan perhimpunan jemaat ini agar benar-benar dapat merasakan kehadiran kuasa Ilahi dalam dirinya. Gembala perlu menjelaskan sasaran-sasaran dalam pelayanan pastoral yang harus dijangkau dalam pelayanan pastoral. Penyusunan rencana dan program kerja ini dapat dilakukan melalui forum rapat khusus staff pelayan dan melalui forum evaluasi pelayanan. Baik pengerja, sekretariat, dan hamba Tuhan yang melayani perlu di koordinir dan diarahkan untuk berusaha mencapai tujuan gereja.

Kedua, Gereja belum memaksimalkan berbagai fasilitas yang ada untuk menunjang pelayanan pastoral konseling secara lebih efektif. Fasilitas yang ada di gereja sebenarnya merupakan sumber daya yang patut dioptimalkan pemanfaatannya bagi jemaat. Contohnya: 1) Warta Jemaat, radio FM, papan pengumuman, dan forum-forum dalam jadwal ibadah sepekan dapat dipergunakan untuk media menyampaikan materi-materi Firman Tuhan tentang pentingnya rasa antusiasme dalam beribadah. 2) Keberadaan hamba Tuhan dan pengerja dapat diperankan secara tepat untuk membantu pelayanan konseling bagi jemaat. 3) Ketersediaan dana yang cukup besar dapat dialokasikan guna pembekalan dan peningkatan kapasitas hamba Tuhan dan pengerja gereja untuk dapat melakukan pelayanan pastoral konseling secara lebih efektif. 4) Karakter jemaat yang mau membuka diri untuk menerima pelayanan pastoral konseling merupakan hal penting untuk disikapi secara pro aktif oleh seluruh tim pelayan.

Ketiga, gembala perlu mengoordinir tim pelayanan yang ada dengan baik. Masing-masing pelayan difungsikan secara tim dan bekerjasama dengan baik guna mencapai tujuan bersama.

Sementara itu perlu diketahui bahwa strategi merupakan hal yang penting untuk diterapkan guna mencapai tujuan yang ingin diraih. Dalam dunia sekuler, untuk mencapai tujuan penggunaan strategi tertentu adalah hal yang biasa dilakukan. Dengan menggunakan strategi, diharapkan ada cara jitu untuk mempercepat, mempermudah dan mengefektifkan langkah serta upaya demi meraih sasaran. Tuhan Yesus membahas tentang penggunaan strategi dengan menyatakan:

"Sebab siapakah di antara kamu yang kalau mau mendirikan sebuah menara tidak duduk dahulu membuat anggaran biayanya, kalau-kalau 
cukup uangnya untuk menyelesaikan pekerjaan itu? Supaya jikalau ia sudah meletakkan dasarnya dan tidak dapat menyelesaikannya, janganjangan semua orang yang melihatnya, mengejek dia, sambil berkata: Orang itu mulai mendirikan, tetapi ia tidak sanggup menyelesaikannya. Atau, raja manakah yang kalau mau pergi berperang melawan raja lain tidak duduk dahulu untuk mempertimbangkan, apakah dengan sepuluh ribu orang ia sanggup menghadapi lawan yang mendatanginya dengan dua puluh ribu orang? Jikalau tidak, ia akan mengirim utusan selama musuh itu masih jauh untuk menanyakan syarat-syarat perdamaian." 31

Jelaslah bahwa Tuhan Yesus menghendaki setiap orang percaya memiliki suatu program kerja secara terencana, terstruktur dan memiliki sasaran target yang jelas dalam melakukan segala sesuatu. Tidak seharusnya melakukan sebuah pekerjaan dengan asal jalan, sekenanya dan minimalis terlebih untuk melayani Tuhan sendiri. Tuhan Yesus juga menghendaki adanya konsep strategi yang perlu disusun oleh seorang pemimpin untuk mengelola aset dan tim kerjanya dalam mencapai suatu tujuan. Dalam hal ini manajemen strategi perlu diupayakan dengan memaksimalkan potensi-potensi yang ada guna meraih target kerja untuk melayani.

\section{SIMPULAN}

Gereja selama ini belum memiliki strategi dalam menerapkan pelayanan pastoral konseling terhadap jemaat yang antusiasme ibadahnya rendah. Gereja selama ini juga kurang tanggap dalam memberikan perhatian dan tindak lanjut terhadap ketidakhadiran jemaat pada jam-jam ibadah di gereja. Hamba Tuhan dan pengerja gereja belum memiliki rencana untuk memantau alasan-alasan atas ketidakhadiran jemaat dalam setiap kegiatan peribadahan di gereja. Kegiatan bezuk baru dilakukan setelah rentang waktu yang terlalu lama yaitu satu sampai dua bulan tidak hadir. Sementara itu, masalah lemahnya antusiasme sering terjadi dalam diri jemaat yang tengah memiliki persoalan dan krisis yang belum tertangani. Gereja seharusnya jangan hanya fokus pada tata liturgi dan pelayanan altar, tetapi perlu lebih memperhatikan kebutuhan psikologis jemaat yang sering membutuhkan pertolongan untuk menghadapi krisis-krisis dalam hidupnya.

Gereja jarang memiliki seorang hamba Tuhan konselor cakap dan terlatih yang dapat menerapkan strategi pelayanan pastoral konseling bagi jemaat. Gembala seringkali tidak mengetahui secara persis kondisi keseharian jemaat yang sewaktu-waktu memerlukan pelayanan pastoral konseling.Disinilah letak perlunya gereja memperlengkapi para pelayan untuk

31 Lukas 14:28-32. 
bisa melayani jemaat secara menyeluruh. Gereja perlu memiliki figur hamba Tuhan konselor yang dapat melakukan pelayanan pastoral konseling secara efektif. Hal tersebut dapat dilakukan melalui pembekalan dan peningkatan kapasitas bagi hamba Tuhan yang memiliki talenta dan kerinduan menjadi konselor Kristen. Tidak kalah pentingnya bagi gembala untuk lebih memperhatikan pelayanan pastoral konseling pada jemaat dengan mengatur waktu untuk melakukan kunjungan pastoral ke rumah jemaat dan untuk melakukan pelayanan konseling.

Penerapan strategi pelayanan pastoral konseling yang tepat akan membantu gereja untuk mengurai masalah lemahnya antusiasme jemaat untuk beribadah. Gembala belum memiliki rencana program, target dan sasaran kerja yang jelas untuk melaksanakan peran pelayanan pastoral. Fasilitas-fasilitas yang ada di gereja seharusnya juga bisa dipergunakan untuk menunjang pelayanan pastoral konseling secara lebih efektif. Termasuk adanya tim pelayanan seharusnya dapat dikoordinir supaya dapat bekerjasama dengan baik. Penerapan strategi pelayanan pastoral konseling dapat dilakukan dengan langkah-langkah sebagai berikut: melibatkan tim yang dimiliki gereja, menguatkan kapasitas hamba Tuhan konselor, melakukan peran pelayanan pastoral konseling secara tepat, menetapkan sasaran dan target pelayanan serta melakukan monitoring dan evaluasi terhadap hasil pelayanan.

Gereja perlu memotivasi dan mengajak seluruh jemaat dan pelayan Tuhan untuk memiliki hubungan pribadi yang indah dengan Tuhan. Jemaat didoktrin untuk memprioritaskan ibadah lebih dari apapun dalam hidupnya dan diarahkan hatinya untuk tetap berjalan dalam pimpinan Roh Kudus. Gereja jangan sampai kehilangan api semangat dan antusiasme dalam beribadah dan menyembah Tuhan Sang Gembala Agung. Pengajaran tentang apa itu ibadah, bagaimana motivasi yang benar dalam beribadah dan tentang antusiasme dalam menyembah Tuhan perlu sering disampaikan kepada jemaat baik melalui khotbah secara tematis, melalui tulisan-tulisan dalam media gereja atau dengan cara-cara lain. Melalui pengajaran dari gereja, jemaat diajak untuk menyadari perilaku-perilaku yang salah dalam beribadah dan komitmen kerohaniannya diharapkan dapat mengalami pembaharuan. Pengajaran yang berulang-ulang dan mendalam akan mendukung keberhasilan penerapan strategi dalam pelayanan pastoral konseling, sebab proses konseling itu sendiri selalu berupaya menolong jemaat untuk memiliki pengetahuan rohani yang benar akan Allah. 


\section{DAFTAR PUSTAKA}

A, Cronbach

1982 Worship in Old Testament, dalam The Interpreter's Dictionary of the Bible, Editor by G.A.Buttrick, R-2 Nashville, Abingdon Press.

Basden, Paul

1999 The Worship Maze, Downers Grove, Illionis: Inter Varsity Press.

Fee, D Gordon

2004 Paulus, Roh Kudus dan Umat Allah, Malang: Gandum Mas.

Gintings, EP

2009 Konseling Pastoral, Bandung: Jurnal Info Media.

Indra, Ichwei G

2008 A Blessing Church Studi Eklesiologi Praktis, Surabaya: Pelayanan Mandiri "Mikhael"

James, D. Berkley

1992 Leadership Handbook of Preaching and Worship, Manila : Christian Letarature Crusade.

Latipun

2001 Psikologi Konseling, Malang:Unmuh.

Manafe, S. Ferdinan

2014 Teologi Ibadah: Ibadah Yang Berkenan, Batu: Literatur YPPII.

Piper, John

1993 Let the Nation be Glad! The Supremacy of God in Missions, Baker Book House, Grand Rapids.

Segler, M. Franklin

1996 Christian Worship, Tennessee : Broadman \& Holman Publiser.

Sondang, P. Siagian

2008 Manajemen Stratejik, Jakarta: Bumi Aksara.

Surayin

2010 Kamus Umum Bahasa Indonesia, Bandung: Yrama Widya. 
Missio Ecclesiae, 8(2), Oktober 2019, 137-154

Susabda, Yakub B

2000 Pastoral Konseling Jilid 2, Malang: Gandum Mas.

Susabda, Yakub B

2003 Pastoral Konseling Jilid 1, Malang: Gandum Mas.

Susabda, Yakub B

2007 Pelayanan Konseling Melalui Telepon, Yogyakarta: Andi.

Tomatala, Magdalena

2003 Konselor Kompeten, Pengantar Konseling Terapi Untuk Pemulihan, Jakarta: YT Leadership Foundation.

Wagner, C. Peter

1997 Gereja Saudara Dapat Bertumbuh, Malang: Gandum Mas.

Wongso, Peter

1999 Tugas Gereja dan Misi Masa Kini, Malang: Literatur SAAT.

1967 New Bible Dictionary, Leicester: Inter-Varsity Press.

2003 Alkitab Terjemahan Baru, Jakarta: Lembaga Alkitab Indonesia. 